\title{
Analisis Pengaruh Ukuran Perusahaan, Profitabilitas, Financial Leverage, Likuiditas, Dan Kepemilikan Institusional Terhadap Perataan Laba Di Perusahaan Manufaktur Sektor Aneka Industri Yang Terdaftar Di BEI (Bursa Effect Indonesia) Periode 2015-2018
}

\author{
Elisa Nur Indah Sari ${ }^{1}$, Dirvi Surya Abbas ${ }^{2}$, M. Zulman Hakim ${ }^{3}$, Arry \\ Eksandy ${ }^{4}$, Hustna Darra ${ }^{5}$ \\ Universitas Muhammadiyah Tangerang ${ }^{1,2,3,4,5}$ \\ Email korespondensi:whibleyelisa@gmail.com
}

\begin{abstract}
Abstrak: Penelitian ini bertujuan untuk menganalisis pengaruh ukuran perusahaan, profitabilitas, financial leverage, likuiditas dan kepemilikan Institusional terhadap Perataan laba di sektor Aneka Industri. Yang terdaftar di bursa Efek Indonesia Periode 2015-2018. Metode sampling untuk digunakan dalam penelitian ini adalah metode purposive sampling. Perusahaan yang mencapai kriteria dalam penelitian ini sebanyak 15 perusahaan Aneka Industri di BEl pada periode 2015 - 2018. Analisis yang digunakan yaitu analisis regresi data panel yang didahului oleh uji chow, uji hausman, dan uji lagrange multiplier. Pengujian hipotesis dilakukan dengan menggunakan uji $F$, uji $R$ aquared dan uji T. Hasil penelitian ini menyimpulkan bahwa ukuran perusahaan, profitabilitas, financial leverage dan likuiditas tidak berpengaruh terhadap Perataan laba sedangkan kepemilikan Institusional Berpengaruh negatif terhadap Perataan laba.

Kata Kunci: Perataan Laba, Ukuran perusahaan, Profitabilitas, Financial Leverage, Likuiditas, Kepemilikan Institutional
\end{abstract}

Laporan keuangan yang merupakan hasil akhir dari proses akuntansi keuangan, umumnya menyajikan laporan posisi keuangan, hasil usaha, dan perubahan posisi keuangan secara wajar sesuai prinsip akuntansi yang diterima umum, Laporan keuangan nantinya dapat dijadikan sebagai sarana informasi dalam mengambil keputusan ekonomi, salah satu informasi yang biasanya digunakan untuk pengambilan suatu keputusan adalah laba. Menurut Beatie, (1994) dalam Harmastuti (2004), perhatian informasi sering berpusat pada laba perusahaan tanpa memperhatikan prosedur yang digunakan untuk menghasilkan laba tersebut, sehingga cenderung mendorong Institusi melakukan manipulasi laba maupun manajemen laba, kelonggaran dalam standar akuntansi membuat Institusi diberikan keleluasan untuk memilih metode akuntansi yang digunakan dalam penyusunan laporan keuangannya, kesempatan tersebut dapat dimanfaatkan agar kinerja Institusi sesuai dengan keinginan pembuat laporan keuangan, yang nantinya dapat mempengaruhi pengguna laporan keuangan dalam proses pengambilan keputusan. Manipulasi laba biasanya dilakukan dengan mengurangi fluktuasi laba dan memaksimalkan atau meminimalkan laba tergantung motivasi Institusi dalam memanipulasi laba tersebut. fluktuasi laba bertujuan agar jumlah laba suatu periode tidak terlalu berbeda dengan jumlah periode sebelumnya dengan menggunakan teknik-teknik tertentu.

Berdasarkan pengamatan telah terjadi lonjakan laba pada PT 
Perusahaan Listrik Negara (Persero) atau PLN dan PT Pertamina (Persero). Jakarta, CNN Indonesia. BUMN tersebut berhasil membukukan kinerja yang kinclong pada akhir 2018. PLN berhasil mencetak laba bersih Rp11,56 triliun sepanjang 2018. Laba itu naik sebesar 162,30 persen atau hampir tiga kali lipat dari laba 2017 yakni Rp4,42 triliun. Padahal, pada kuartal III 2019, PLN masih mengantongi rugi sebesar Rp18,48 triliun akibat rugi selisih kurs sebesar Rp17,32 triliun. Sementara teranyar, PT Pertamina (Persero) baru saja mengumumkan laba bersih sepanjang tahun lalu sebesar US\$2,53 miliar atau sekitar Rp35,99 triliun. Meski turun tipis dibanding tahun lalu sebesar US\$2,54 miliar, capaian ini lompat dibanding kuartal III 2018 yang baru mencatatkan laba Rp5 triliun.

Berdasarkan fenomena diatas maka dapat disimpulkan bahwa perataan laba bisa terjadi kapan saja tanpa kita sadari dan memiliki dampak yang besar bukan hanya pada perusahaan itu sendiri tapi juga bisa memberi dampak kepada masyarakat yang berhubungan dengan perusahaan pelaku perataan laba.

\section{METODE}

Jenis data yang digunakan dalam penelitian ini adalah data kuantitatif. Sumber data yang digunakan dalam penelitian ini adalah data sekunder. Penelitian ini akan menggunakan data sekunder yang diperoleh dari laporan keuangan perusahaan aneka industri yang terdaftar di Bursa Efek Indonesia (BEI) selama periode 2015-2018, yang diakses melalui website resmi BEI yaitu www.idx.co.id.

Metode pengambilan sampel yang digunakan adalah Purposive Sampling, yaitu metode pemilihan sampel dimana dilakukannya pertimbangan-pertimbangan tertentu dan pertimbangan yang diambil itu berdasarkan tujuan penelitian. Sampel untuk penelitian ini adalah pada sektor Aneka Industry yang terdaftar di Bursa Efek Indonesia (BEI) selama tahun 2015-2018. Dari hasil pemilihan sampel dengan menggunakan Purposive Sampling terpilih 15 perusahaan yang memenuhi kriteria dengan periode 4 tahun. Jadi data yang digunakan dalam penelitian ini sebanyak 60 data observasi.

\section{Variable dependen $(Y)$}

adalah variable terikat atau biasa disebut output, kriterisn,atau konsekuen. Variable dependen dalam penelitian ini adalah perataan laba.

Perataan laba (income smoothing) adalah usaha yang disengaja untuk meratakan atau memfluktuasikan tingkat laba sehingga pada saat sekarang dipandang normal bagi suatu perusahaan. Untuk mengidentifikasi apakah perusahaan tersebut melakukan tindakan perataan laba, dapat menggunakan indeks Eckel. 1981). Adapun perhitungan indeks eckel dirumuskan sebagai berikut :

$$
\text { Indeks Perataan Laba }=(\mathrm{CV} \Delta \mathrm{I}) /(\mathrm{CV} \Delta \mathrm{S})
$$

Keterangan :

$\Delta \mathrm{I}$ : Perubahan Laba dalam suatu periode $\Delta S$ : Perubahan pendapatan dalam suatu periode 
CV : Koefisien variasi dari variabel yaitu standar deviasi dibagi dengan nilai yang diharapkan.

CV $\Delta \mathrm{I}=$ Koefesien variasi untuk perubahan laba

$\mathrm{CV} \Delta \mathrm{S}=$ Koefisien variasi untuk perubahan pendapatan

di mana,

\begin{tabular}{|c|}
\hline 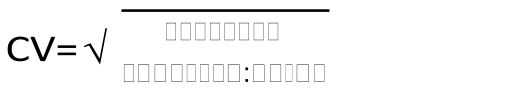 \\
\hline $\mathrm{CV} \Delta \mathrm{S}$ atau $\mathrm{CV} \Delta \mathrm{I}=\sqrt{\sum(\Delta \square-\Delta \square} ; \Delta$ \\
\hline
\end{tabular}

$\Delta x=$ perubahan laba (I) atau penjualan (S)

$\Delta x=$ rata-rata perubahan laba $(\mathrm{I})$ atau penjualan $(\mathrm{S})$

$\mathrm{n}=$ banyaknya tahun yang diamati

-Jika nilai Indeks Eckel $\geq 1$, maka perusahaan tidak melakukan perataan laba dan diberi simbol 0.

-Jika nilai Indeks Eckel < 1, maka perusahaan melakukan praktik perataan laba dan diberi simbol 1.

\section{Variabel Independen (Bebas)}

a. Ukuran Perusahaan (X1)

Ukuran perusahaan umumnya dinilai dari besarnya aktiva perusahaan. Moses (1987) dalam Suwito dan Herawaty (2005) menemukan bukti bahwa perusahaan- perusahaan yang lebih besar memiliki dorongan yang lebih besar untuk melakukan perataan laba dibandingkan dengan perusahaan-perusahaan yang lebih kecil karena perusahaan-perusahaan yang lebih besar menjadi subyek pemeriksaan (pengawasan yang lebih ketat dari pemerintah dan masyarakat umum/general public). Oleh karena itu peneliti berpendapat ukuran perusahaan patut diduga merupakan salah satu faktor dilakukanya praktik perataan laba. Ukuran perusahaan dihitung dengan menggunakan logaritma natural dari total asset, sehingga dapat dirumuskan sebagai berikut:

Ukuran perusahaan $=$ Ln Total Asset

(Sumber: Budiasih, 2009)

\section{b. Profitabilitas (X2)}

Profitabilitas adalah hasil bersih dari serangkaian kebijakan dan keputusan yang menunjukkan pengaruh gabungan dari kebijakan likuiditas, menajemen aktiva dan manajemen utang terhadap hasil operasi (Brigham dan Houston,2001). Profitabilitas perusahaan diukur dengan kesuksesan perusahaan dan kemampuan menggunakan aktivanya secara produktif.

Dalam hal ini laba yang digunakan adalah laba setelah pajak (EAT). Perhitungan ROA menurut Wild dkk (2005) adalah sebagai berikut :

Return On Asset $(\mathrm{ROA})=($ Earning After Tax )/(Total Aktiva) x $100 \%$

(Sumber: Wild dkk., 2005) 


\section{c. Financial Leverage (X3)}

Financial leverage merupakan kemampuan untuk mengukur perusahaan dalam membayar seluruh kewajibannya, baik jangka pendek maupun jangka panjang apabila dilikuidasi. Financial Leverage diukur dengan Debt To Equity Ratio (DER). Rumus DER sebagai berikut :

DER = Total Hutang Ekuitas

(Sumber: Murniati et al., 2018)

\section{d. Likuiditas (X4)}

Variabel likuiditas diukur dengan menggunakan rasio lancar yaitu antara asset lancar dengan utang lancer dengan rumus

\begin{tabular}{|lll}
\hline Rasio Lancar & $:$ (Asset Lancar)/(Utang \\
Lancar)
\end{tabular}

(Sumber: Wibowo dan Diyah, 2011)

\section{e. $\quad$ Kepemilikan Institusional (X5)}

Kepemilikan Institusional diukur dari jumlah persentase kepemilikan saham dari manajemen perusahaan yang meliputi Institusi maupun dewan direksi. Indikator yang digunakan untuk mengukur kepemilikan Institusional adalah persentase jumlah saham yang dimiliki pihak institusi dari seluruh modal perusahaan yang beredar yang dimiliki. Berikut rumus untuk mengukur kepemilikan Institusional :

$$
\text { Kepemilikan Institusional }=\text { Total Shares held by institutional }
$$

(Sumber: Koh, 2003)

Dalam penelitian ini, teknik analisis data yang digunakan adalah analisis regresi data panel dengan bantuan software pengolah data statistik yaitu Eviews 10.0. Berikut ini merupakan metode analisis data yang digunakan dalam penelitian ini seabagai berikut:

\section{A. Analisis Statistik Deskriptif}

Statistik deskriptif dapat diartikan sebagai gambaran umum terkait objek penelitian yang dijadikan sampel penelitian. Data statistik deskriptif terdiri dari mean, median, maximum, minimum, standard deviation, skewness, kurtosis, Jarque-Bera, dan probability. (Eksandy, 2018).

\section{B. Estimasi Model Regresi Data Panel}

Model Regresi Data Panel terbagi menjadi 3 model yaitu common effects model, fixed effects model, dan random effects model.

\section{Teknik Pemilihan Model Regresi Data Panel}

Teknik Pemilihan Model Regresi Data Panel terbagi menjadi 3 model yaitu uji chow, uji hausman, dan uji lagrange multiplier.

\section{Uji Chow}

Uji Chow adalah salah satu teknik pemilihan model regresi data panel yang digunakan untuk memilih salah satu model diantara dua model berikut yaitu: common effect model (CEM) atau fixed effect model (FEM) (Eksandy, 2018). Teknik pengujian ini dapat diliat dari nilai Probabilitas (Prob.) Cross-section F dan Cross-section Chi- square dengan 
hipotesis sebagai berikut:

$\mathrm{HO}=$ Common Effect Model (CEM) lebih layak digunakan jika Probability Cross- section $\mathrm{F}$ dan Cross-section Chi-square $>(0,05)$

$\mathrm{Ha}=$ Fixed Effect Model (FEM) lebih layak digunakan jika Probability Cross-section $\mathrm{F}$ dan Cross-section Chi-square $<(0,05)$

\section{Uji Hausman}

Uji Hausman adalah salah satu teknik pemilihan model regresi data panel yang digunakan untuk memilih salah satu model diantara dua model berikut yaitu: Random Effect Model (REM) atau Fixed Effect Model (FEM) (Eksandy, 2018). Teknik pengujian ini dapat dilihat dari nilai Probabilitas (Prob.) Cross-section Random dengan hipotesis sebagai berikut:

$\mathrm{HO}=$ Model Randoom Effect Model (REM) lebih layak digunakan jika nilai probability cross- section random $>(0,05)$

$\mathrm{Ha}=$ Model Fixed Effect Model (FEM) lebih layak digunakan jika nilai probability cross- section random $<(0,05)$

3. Uji Lagrange Multiplier

Uji Lagrange Multiplier adalah salah satu teknik pemilihan model regresi data panel yang digunakan untuk memilih salah satu model diantara dua model berikut yaitu: Random Effect Model (REM) atau Common Effect Model (CEM). Pengujian ini dapat dilihat pada nilai Probabilitas (Prob.) (Eksandy, 2018). Breush-pagan dengan hipotetis sebagai berikut:

$\mathrm{HO}=$ Model Common Effect Model (CEM) lebih layak digunakan jika nilai probability cross-section Breush-pagan $>(0,05)$

$\mathrm{Ha}=$ Model Random Effect Model (REM) lebih layak digunakan jika nilai probability cross- section Breush-pagan $<(0,05)$

4. Uji Asumsi Klasik

Uji Asumsi Klasik adalah suatu pengujian yang hanya dilakukan apabila model regresi yang digunakan dalam bentuk Common Effects Model atau Fixed Effects Model. Sebaliknya apabila persamaan regresi lebih cocok menggunakan Random Effects Model maka pengujian ini tidak perlu dilakukan. Uji Asumsi Klasik terdiri dari uji Linieritas, Autokorelasi, Multikolineritas, Normalitas, dan Heteroskedastisitas. Walaupun demikian, tidak semua uji dilakukan dalam regresi data panel, hanya uji Multikolineritas dan Heteroskedastisitas saja yang diperlukan. (Eksandy, 2018).

D. Uji Hipotesis

Uji hipotesis memiliki tiga jenis pengujian yaitu sebagai berikut:

1.Uji Kelayakan Model (Uji F)

Adapun hipotesis dalam uji $\mathrm{F}$ adalah sebagai berikut:

Berdasarkan perbandingan F-statistic dengan $\mathrm{F}$ tabel

$\mathrm{HO}$ : Jika besar nilai F-statistic $<\mathrm{F}$ Tabel

$\mathrm{Ha}$ : Jika besar nilai F-statistic $>\mathrm{F}$ table Berdasarkan Probabilitas

$\mathrm{HO}$ : Jika besar nilai prob (F-statistic) $>\alpha 0,05$

$\mathrm{Ha}$ : Jika besar nilai prob (F-statistic) $<\alpha 0,05$

2.Uji Koefisien Determinasi (R2)

Terdapat kriteria dalam pengujian Koefisien Determinasi dimana besar 
nilai R-squared berada antara 0 sampai 1 , penjelasannya sebagai berikut: a.Nilai R-squared harus berkisar 0 sampai 1

b.Jika nilai R-squared sama dengan 1, berarti naik atau turunnya variabel terikat $(Y)$ 100\% dipengaruhi oleh variabel bebas $(X)$

c.Jika nilai $\mathrm{R}$-squared sama dengan 0 , berarti tidak ada hubungan sama sekali antara variabel independen dengan variabel dependen.

3.Uji Hipotesis Secara Parsial (Uji T)

Hipotesis dalam uji T adalah sebagai berikut:

Berdasarkan perbandingan T-statistic dengan $\mathrm{T}$ tabel

$\mathrm{HO}$ : Jika besar nilai T-statistic $<\mathrm{T}$ Tabel Ha : Jika besar nilai T-statistic > $T$ tabel Berdasarkan Probabilitas

$\mathrm{HO}$ : Jika besar nilai prob (T-statistic) $>\alpha 0,05$

$\mathrm{Ha}$ : Jika besar nilai prob (T-statistic) $<a 0,05$

4.Analisis Regresi Data Panel

Analisis Regresi Data Panel adalah gabungan antara data cross section dan data time series, dimana unit cross section yang sama diukur pada waktu yang berbeda. Maka dapat disimpulkan bahwa data panel merupakan data yang diperoleh dari beberapa sampel yang diamati dalam jangka waktu tertentu (Eksandy, 2018).

Berikut ini adalah persamaan regresi data panel adalah sebagai berikut:

Keterangan:

$$
\mathrm{Y}=\mathrm{b} 0+\mathrm{b} 1 \times 1+\mathrm{b} 2 \times 2+\mathrm{b} 3 \times 3+\mathrm{b} 4 \times 4+\mathrm{b} 5 \times 5+e
$$

$\mathrm{Y}=$ Variabel dependent Perataan Laba

b0 = Konstanta

b1-b7=Koefisien regresi variable independent

X1 = UKURAN PERUSAHAAN

$X 2=$ PROFITABILITAS

X3 =FINANCIAL LEVERAGE

$X 4=$ LIKUIDITAS

X5 = KEPEMILIKAN INSTITUSIONAL

$\mathrm{e}=$ standar error

\section{HASIL}

\section{Hasil Analisis Statistik Deskriptif}

Tabel 4.1 Analisis Statistik Deskriptif

\begin{tabular}{|c|c|c|c|c|c|c|}
\hline 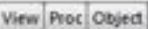 & Pint Dane & Sanple: & Sncet stass & spes & & \\
\hline & $r$ & $x 1$ & $x_{2}$ & $x_{3}$ & $x_{4}$ & $\times 5$ \\
\hline Mean & 0.989733 & 20. 34184 & 0.065178 & 0.906756 & 1.60578 & 0.653489 \\
\hline Medisn & 0935000 & 27.94900 & 0.043000 & 0.706000 & 1.631000 & 0.837000 \\
\hline Masemum & 3.146000 & 33.47400 & 0.227000 & 2522000 & 4.144000 & 0991000 \\
\hline Minimum & 0.018000 & 26.68400 & 0.000000 & 0.254000 & 0.549000 & 0.084000 \\
\hline std Dev & 0.774944 & 1.626272 & 0.059813 & 0.653311 & 0.855625 & 0.345756 \\
\hline skcowness & 1236322 & 1,933711 & 1.345087 & 1322475 & 1042794 & .0 .653156 \\
\hline Kuntosis & 4657677 & 6525724 & 4.290102 & 3556845 & 3250324 & 1746711 \\
\hline Jarove-ders & 16.61598 & 51.35191 & 16.71030 & 13.69844 & 8.261730 & 6.144720 \\
\hline Probsaliay & 0.000247 & 0.000000 & 0.000235 & 0.001080 & $0.015 \% 00$ & 0.046312 \\
\hline Sum & 4453800 & 1276.383 & 2933000 & 40.80400 & 83.72600 & 29.40700 \\
\hline Sum Sq. Dev. & 28.42365 & 118.3694 & 0.157417 & 19.35919 & 33.04589 & 5280079 \\
\hline Observations & 45 & 45 & 45 & 45 & 45 & 45 \\
\hline
\end{tabular}


Sumber: Hasil Olahan Eviews 10.0, 2020.

Pada tabel di atas, dapat dijelaskan bahwa jumlah data (observations) yang digunakan dalam penelitian ini sebanyak 45 data. Pada tabel di atas dapat dideskripsikan bahwa PerataanLaba sebagai variabel dependen (y) menghasilkan nilai minimum 0.018 nilai maksimum 3.146 nilai mean 0.9897 dengan standar deviasi $0.774 \mathrm{Hal}$ ini menunjukkan bahwa rata-rata adalah sebesar $98.97 \%$ dan standar deviasi sebesar $77.49 \%$ dari perusahaan-perusahaan sampel yang diteliti dan memiliki perbedaan yang relatif besar.

\section{Estimasi Model Regresi Data Panel.}

a. Common Effect Model (CEM)

Tabel 4.2 Common Effect Model

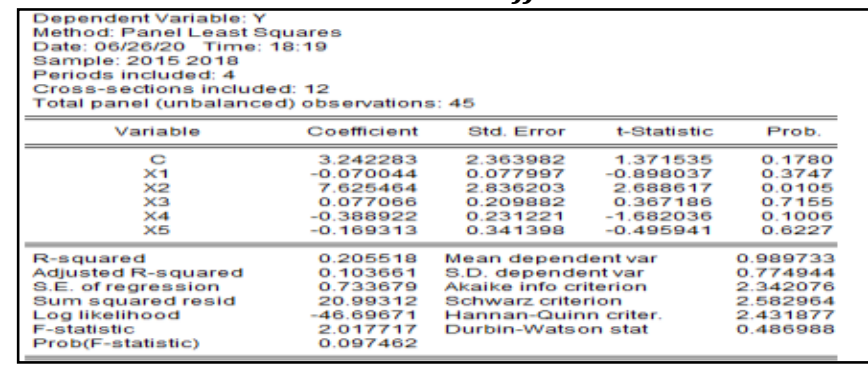

Sumber: Hasil Olahan Eviews 10.0, 2020.

b. Fixed Effect Model (FEM)

Tabel 4.3 Fixed Effect Model

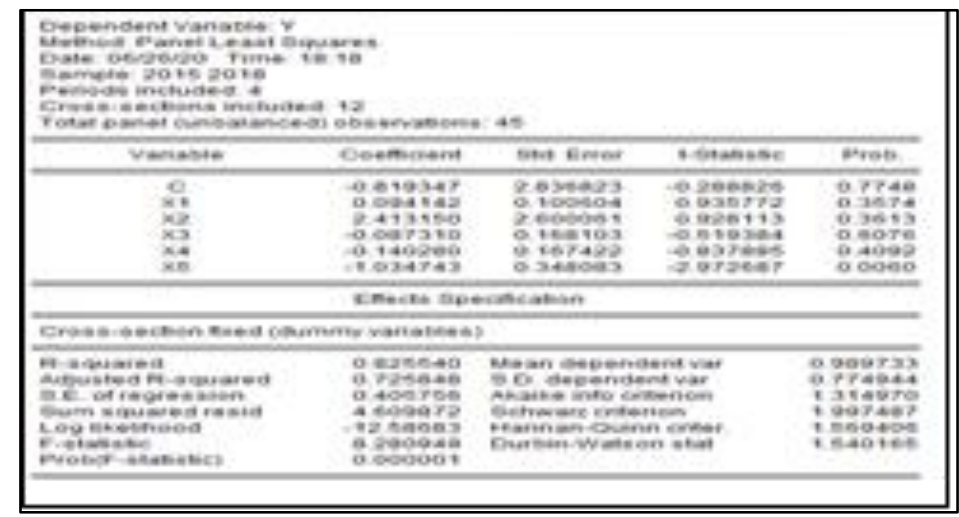

Sumber: Hasil Olahan Eviews 10.0, 2020. 
c. Random Effect Model (REM)

Tabel 4.4 Random Effect Model

\section{Pemilihan Model Regresi Data Panel}

\begin{tabular}{|c|c|c|c|c|}
\hline \multicolumn{5}{|c|}{ 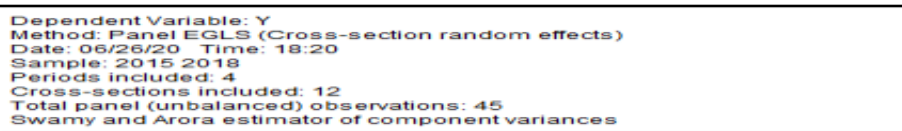 } \\
\hline variable & Coemcient & Sta. Error & t-Statistic & Prob. \\
\hline $\begin{array}{l}0 \\
\times 1 \\
\times 2 \\
\times 3 \\
\times 4 \\
\times 5\end{array}$ & $\begin{array}{r}0.606431 \\
0.038088 \\
3.650940 \\
-0.0430909 \\
-0.195969 \\
-0.813534 \\
-0.81954\end{array}$ & $\begin{array}{l}2.490220 \\
0.087297 \\
2.420851 \\
0.160218 \\
0.1598154 \\
0.313675\end{array}$ & $\begin{array}{r}0.243525 \\
0.436304 \\
1508122 \\
-1.268985 \\
-1.226306 \\
-2.593555\end{array}$ & $\begin{array}{l}.8089 \\
0.6650 \\
0.1396 \\
0.7894 \\
0.2274 \\
0.0133\end{array}$ \\
\hline \multicolumn{3}{|c|}{ Errects Specification } & S.D. & Rho \\
\hline $\begin{array}{l}\text { Cross-section random } \\
\text { Idilosyncratic random }\end{array}$ & & & $\begin{array}{l}0.779755 \\
0.405756\end{array}$ & $\begin{array}{l}0.7869 \\
0.2131\end{array}$ \\
\hline \multicolumn{5}{|c|}{ Weighted Statistics } \\
\hline 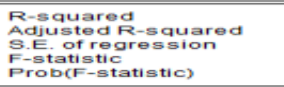 & $\begin{array}{l}0.344233 \\
0.260160 \\
0.3900086 \\
4.094468 \\
0.004392\end{array}$ & \multicolumn{2}{|c|}{ 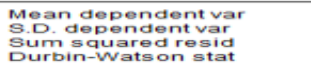 } & $\begin{array}{l}.254664 \\
0.455424 \\
5.934502 \\
1.218947\end{array}$ \\
\hline \multicolumn{5}{|c|}{ Unweighted Statistics } \\
\hline $\begin{array}{l}\text { R-squared } \\
\text { Sum squared resid }\end{array}$ & $\begin{array}{l}0.081577 \\
24.26810\end{array}$ & $\begin{array}{l}\text { Mean depenc } \\
\text { Durbin-Wats }\end{array}$ & $\begin{array}{l}\text { intar } \\
\text { intat }\end{array}$ & $\begin{array}{l}0.989733 \\
0.298080\end{array}$ \\
\hline
\end{tabular}

Sumber: Hasil Olahan Eviews 10.0, 2020.

\section{A. Uji Chow}

Tabel 4.5 Uji Chow

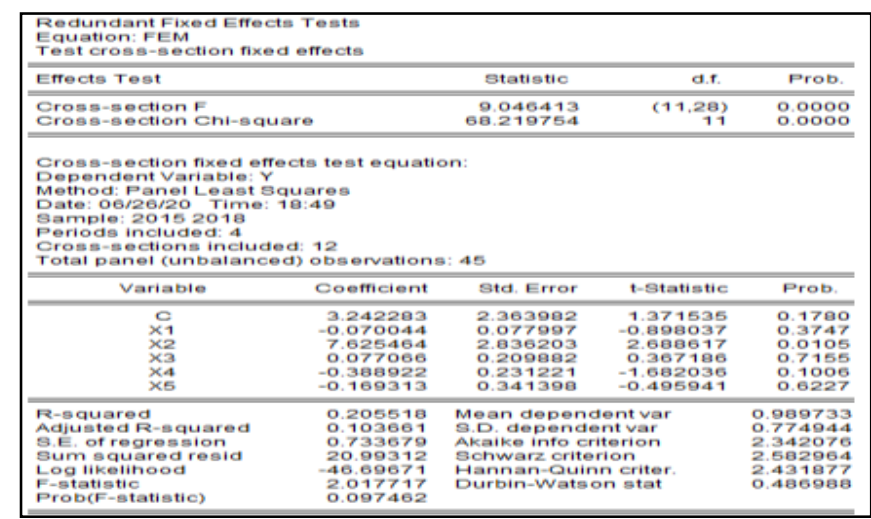

Sumber: Hasil Olahan Eviews 10.0, 2020.

Dilihat dari hasil olah data diatas, nilai Prob cross-section $\mathrm{F}$ dan crosssection chisquare $<(0,05)$ maka dapat disimpulkan bahwa Fixed Effect Model (FEM) lebih layak digunakan dibandingkan Common Effect Model (CEM). 


\section{B. Uji Hausman}

Tabel 4.6 Uji Hausman

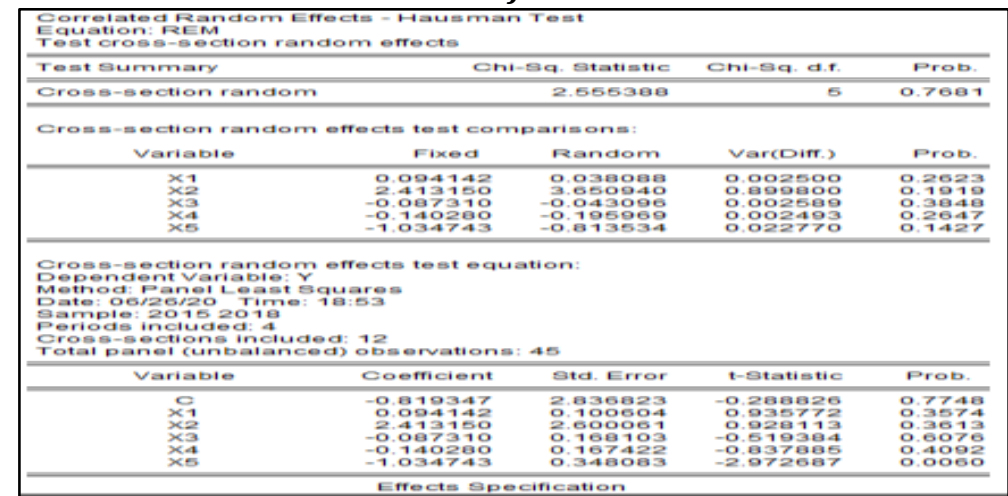

Sumber: Hasil Olahan Eviews 10.0, 2020.

Berdasarkan hasil perhitungan diatas, nilai Prob cross-section random < $(0,05)$ maka dapat disimpulkan bahwa Random Effect Model (REM) lebih layak digunakan dibandingkan Fixed Effect Model (FEM).

C. Uji Lagrange Multiplier

Tabel 4.7 Uji Lagrange Multiplier

\begin{tabular}{|c|c|c|c|}
\hline \multicolumn{4}{|c|}{$\begin{array}{l}\text { Lagrange multiplier (LM) test for panel data } \\
\text { Date: } 06 / 26 / 20 \text { Time: } 18: 06 \\
\text { Sample: } 20152018 \\
\text { Total panel observations: } 45 \\
\text { Probability in O }\end{array}$} \\
\hline $\begin{array}{l}\text { Null (no rand. effect) } \\
\text { Alternative }\end{array}$ & $\begin{array}{l}\text { Cross-section } \\
\text { One-sided }\end{array}$ & $\begin{array}{c}\text { Period } \\
\text { One-sided }\end{array}$ & Both \\
\hline Breusch-Pagan & $\begin{array}{l}27.12046 \\
(0.0000)\end{array}$ & $\begin{array}{l}0.221892 \\
(0.6376)\end{array}$ & $\begin{array}{l}27.34235 \\
(0.0000)\end{array}$ \\
\hline Honda & $\begin{array}{l}5.207731 \\
(0.0000)\end{array}$ & $\begin{array}{c}-0.471054 \\
(0.6812)\end{array}$ & $\begin{array}{l}3.349336 \\
(0.0004)\end{array}$ \\
\hline King-Wu & $\begin{array}{l}5.207731 \\
(0.0000)\end{array}$ & $\begin{array}{c}-0.471054 \\
(0.6812)\end{array}$ & $\begin{array}{l}2.039517 \\
(0.0207)\end{array}$ \\
\hline GHM & - & - & $\begin{array}{l}27.12046 \\
(0.0000)\end{array}$ \\
\hline
\end{tabular}

Sumber: Hasil Olahan Eviews 10.0, 2020.

Menurut hasil olahan data diatas dengan nilai Prob cross-section breuschpagan $>(0,05)$ maka dapat disimpulkan bahwa Random Effect Model (REM) lebih layak digunakan dibandingkan Common Effect Model (CEM).

D. Kesimpulan Model

Hasil pengujian disajikan dalam table sebagai berikut:

Tabel 4.1 Kesimpulan model

\begin{tabular}{|l|l|l|}
\hline no & Metode & Hasil \\
\hline 1 & uji chow & FEM \\
\hline 2 & uji haussman & REM \\
\hline 3 & uji lagrange & REM \\
\hline
\end{tabular}

\section{Kesimpulan Pemilihan Model Regresi}

Model Regresi Data Panel yang akan digunakan dalam Uji Hipotesis dan Persamaan Regresi Data Panel adalah model Common Effect Model (CEM), maka diperlukan Uji Hipotesis.

\section{Pengujian Hipotesis}


Uji hipotesis memiliki tiga jenis pengujian yaitu sebagai berikut:

a.Uji Kelayakan Model (Uji F)

Tabel 4.10 Uji Kelayakan Model (F)

\begin{tabular}{|lll|}
\hline \hline R-squared & 0.344233 & Mean dependent var \\
Adjusted R-squared & 0.260160 & S.D. dependent var \\
S.E. of regression & 0.390086 & Sum squared resid \\
F-statistic & 4.094468 & Durbin-Watson stat \\
Prob(F-statistic) & 0.004392 & \\
\hline \hline & Unweighted Statistics \\
\hline \hline R-squared & 0.081577 & Mean dependent var \\
Sum squared resid & 24.26810 & Durbin-Watson stat \\
\hline \hline
\end{tabular}

Sumber: Hasil Olahan Eviews 10.0, 2020.

Berdasarkan hasil tabel Fixed Effect Model yang ditampilkan pada table diatas menunjukkan bahwa nilai F-statistic sebesar 4.457310, sementara F-Tabel dengan tingkat $\alpha=5 \%$, df1 $(\mathrm{k}-1)=5$ dan df2 $(\mathrm{n}-\mathrm{k})=40$ didapat nilai $F$ Tabel sebesar 2.35. Dengan demikian F-statistic (4.094468) $>F$ Tabel (2.45) dan nilai Prob(Fstatistic) $0.004392<0,05$ maka dapat disimpulkan bahwa $\mathrm{Ha}$ diterima, maka dengan demikian dapat disimpulkan bahwa penelitian ini layak untuk dilanjutkan karena variabel variabel independen dalam penelitian ini yang terdiri dari Ukuran perusahaan, profitabilitas, Financial leverage, likuiditas, dan kepemilikan institusional secara bersama-sama memiliki pengaruh terhadap variabel dependen Perataan Laba.

\section{b. Uji T Parsial}

Tabel 4.12 Uji T Parsial

\begin{tabular}{|crrrr|}
\hline Variable & Coefficient & Std. Error & t-Statistic & Prob. \\
\hline \hline C & 0.606431 & 2.490220 & 0.243525 & 0.8089 \\
X1 & 0.038088 & 0.087297 & 0.436304 & 0.6650 \\
X2 & 3.650940 & 2.420851 & 1.508122 & 0.1396 \\
X3 & -0.043096 & 0.160218 & -0.268985 & 0.7894 \\
X4 & -0.195969 & 0.159804 & -1.226308 & 0.2274 \\
X5 & -0.813534 & 0.313675 & -2.593555 & 0.0133 \\
\hline
\end{tabular}

Sumber: Hasil Olahan Eviews 10.0, 2020.

Dari hasil yang ditampilkan pada tabel diatas menunjukan bahwahasil

uji $t$ variabel Ukuran perusahaan, profitabilitas, Financial leverage,likuiditas,dan kepemilikan institusional terhadap Perataan Laba adalah sebagai berikut:

1. Nilai t-statistic Ukuran perusahaan (X1) sebesar 0.986879 , sementara $t$ Tabel dengan tingkat $\alpha=5 \%$, df $(n-k)=40$ didapat nilai $t$ Tabel sebesar 2.02269 .

Dengan demikian t-statistic Size < t Tabel (2.02269) dan nilai Prob. $0.436304>0,05$ maka dapat disimpulkan bahwa variabel Ukuran perusahaan dalam penelitian ini tidak memiliki pengaruh terhadap pengungkapan Perataan Laba. Dengan demikian, $\mathrm{H} 1$ dalam penelitian ini ditolak.

2.Nilai t-statistic profitabilitas sebesar 1.508122, sementara $t$ Tabel dengan tingkat $\alpha=5 \%$, df $(n-k)=40$ didapat nilai t Tabel sebesar 2.02269 . Dengan demikian t-statistic Leverage < t Tabel (2.02269) dan nilai Prob. 
> 0,05 maka dapat disimpulkan bahwa variabel profitabilitas dalam penelitian ini tidak memiliki pengaruh terhadap pengungkapan Perataan Laba. Dengan demikian, $\mathrm{H} 2$ dalam penelitian ini ditolak.

3.Financial leverage $t$ Tabel dengan tingkat $\alpha=5 \%$, df $(n-k)=40$ didapat nilai t Tabel sebesar 2.02269. Dengan demikian t-statistic PROF > t Tabel (2.02269) dan nilai Prob. - $0.268985>0,05$ maka dapat disimpulkan bahwa variabel ini tidak dalam penelitian ini memiliki pengaruh terhadap perataan Laba. Dengan demikian, H3 dalam penelitian ini ditolak.

4.Nilai t-statistic Likuiditas (LIK) sebesar - 1.226308, sementara t Tabel dengan tingkat $\alpha=5 \%$, df $(n-k)=40$ didapat nilai t Tabel sebesar 2.02269 . Dengan demikian t-statistic LIK > t Tabel (2.02269) dan nilai Prob > 0,05 maka dapat disimpulkan bahwa variabel Likuiditas (LIK) dalam penelitian ini tidak memiliki pengaruh terhadap perataan Laba. Dengan demikian, $\mathrm{H} 4$ dalam penelitian ini ditolak.

5.Nilai t-statistic Kepemilikan institusional sebesar -2.593555 , sementara t Tabel dengan tingkat $\alpha=5 \%$, df $(n-k)=40$ didapat nilai $t$ Tabel sebesar 2.02269. Dengan demikian t- statistic > t Tabel (2.02269) dan nilai Prob. < 0,05 maka dapat disimpulkan bahwa variabel kepemilikan institusional dalam penelitian ini memiliki pengaruh negative terhadap pengungkapan Perataan Laba. Dengan demikian, H5 dalam penelitian ini diterima

\section{Teori Agensi}

Teori yang berkaitan dengan variable perataan laba adalah teori agensi. Agency Teori sangat berkaitan dengan tindakan praktik perataan laba yang dilakukan oleh perusahaan. Dimana prinsipal sebagai pemilik modal memiliki akses pada informasi internal perusahaan sedangkan agen sebagai pelaku dalam praktek operasional perusahaan mempunyai informasi tentang operasi dan kinerja perusahaan secara riil dan menyeluruh.

\section{Teori Stewardship}

Teori ini menggambarkan situasi dimana para manajer tidaklah termotivasi oleh tujuan-tujuan individu tetapi lebih ditujukan pada sasaran hasil utama mereka untuk kepentingan organisasi.

Teori ini sangat berkaitan dengan variable perataan laba dimana para eksekutif atau steward yang memiliki perilaku yang dapat dibentuk agar selalu dapat diajak bekerjasama dalam organisasi,berperilaku kolektif serta berkelompok dengan utilitas yang tinggi daripada individunya dan selalu bersedia melayani sehingga akan memaksimumkan kinerja keuangan perusahaan dengan menghasilkan laporan keuangan perusahaan dengan menghhasilkan laporan keuangan yang berkualitas dan memberikan informasi laba yang kredibel yang bebas dari manipulasi atau kecurangan dan akan membentuk image perusahaan yang baik sehingga menurunkan terjadinya Tindakan perataan laba.

\section{Signalling Theory}

Signalling theory mempunyai hubungan dengan variable ukuran 
perusahaan dan variable profitabilitas dimana perusahaan yang besar menunjukan perusahaan mengalami perkembangan sehingga akan memberikan sinyal yang baik kepada pihak luar seperti para investor yang memberikan respon positif pada perusahaan tersebut. Sehingga perusahaan yang berukuran besar akan mengungkapkan informasi yang lebih lengkap.

Hubungannya dengan profitabilitas adalah Ketika perusahaan dengan tingkat profitabilitas yang tinggi akan menggunakan informasi keuangannya untuk mengirim sinyal kepada pasar. Laporan yang mempunyai tingkat profitabilitas yang tinggi menunjukan prospek perusahaan baik,sehingga investor akan merespon positif sinyal tersebut dan nilai perusahaan akan meningkat.

\section{Penelitian terdahulu dan Interpretasi penelitian}

\section{a. Pengaruh ukuran perusahaan terhadap perataan laba}

Ukuran perusahaan dalam penelitian ini tidak memiliki pengaruh terhadap pengungkapan Perataan Laba. Penelitian ini didukung oleh peneltian terdahulu yang dilakukan Ashari dkk (1994) di Singapura yang tidak berhasil membuktikan bahwa besaran perusahaan merupakan faktor pendorong terjadinya praktik perataan laba.

\section{b. Pengaruh Profitabilitas terhadap perataan laba}

Variabel Profitabilitas dalam penelitian ini tidak memiliki pengaruh terhadap perataan laba. Hal ini sejalan dengan penelitian Kurniasih dan Sri (2012) yang menyimpulkan bahwa profitabilitas tidak berpengaruh signifikan terhadap praktik perataan laba. Selain itu, penelitian sejalan juga dilakukan oleh Indarti dan Astri (2015) yang mengatakan bahwa profitabilitas tidak berpengaruh signifikan terhadap praktik perataan laba.

\section{c. Pengaruh Financial Leverage terhadap perataan laba}

Variabel Financial Leverage dalam penelitian ini tidak memiliki pengaruh terhadap perataan Laba. Hal ini sejalan dengan penelitian Pratiwi (2013) menyimpulkan bahwa financial leverage tidak berpengaruh terhadap praktik perataan laba.

d. Pengaruh Likuiditas terhadap perataan laba

Variabel Likuiditas dalam penelitian ini tidak memiliki pengaruh terhadap perataan Laba.hal ini sejalan dengan penelitian Ludmila Sofia Pratnatika (2018) yang menyatakan bahwa likuiditas tidak memiliki pengaruh terhadap pertaan laba

e. $\quad$ Pengaruh Kepemilikan Institusional terhadap perataan laba

Variabel kepemilikan institusional dalam penelitian ini memiliki pengaruh negative terhadap pengungkapan Perataan Laba.hal ini sejalan dengan penelitian Uswatun hasana,Gagaring Pagalung dan Rahmawati HS yang menyatakan bahwa kepemilikan institusional berpengaruh negative terhadap perataan laba.

\section{B. Keterbatasan}

Keterbatasan yang terdapat dalam penelitian ini yaitu :

1.Penelitian ini hanya menggunakan periode penelitian yang singkat yaitu hanya 4 tahun periode saja, 
2.Sampel penelitian ini hanya diambil pada satu sektor saja yaitu sektor Aneka Industri yang terdaftar di BEl.

3.Penggunaan variabel yang digunakan dalam penelitian ini hanya berkaitan dengan rasio keuangan saja.

\section{KESIMPULAN}

Dilihat dari hasil penelitian yang telah dilakukan penulis, maka dapat disimpulkan :

1.Ukuran Perusahaan tidak memiliki pengaruh terhadap pengungkapan

Perataan Laba.

2.Profitabilitas tidak memiliki pengaruh terhadap pengungkapan Perataan Laba.

3.Financial Leverage tidak memiliki pengaruh terhadap perataan Laba

4.Likuiditas tidak memiliki pengaruh terhadap perataan Laba.

5.Kepemilikan institusional memiliki pengaruh negative terhadap

\section{DAFTAR PUSTAKA}

ABIPRAYU, K. B. (2011). Pengaruh Profitabilitas, Ukuran Perusahaan, Financial Leverage, Kualitas Audit, Dan Dividend Payout Ratio Terhadap Perataan Laba (Studi Kasus Pada Perusahaan Manufaktur Yang Terdaftar Di Bursa Efek Indonesia Tahun 2006-2009)

Agustianto, R. N. (2014). Analisis Faktor - Faktor Yang Berpengaruh Terhadap Perataan Laba

BESTIVANO, W. (2013). Pengaruh Ukuran Perusahaan, Umur Perusahaan, Profitabilitas, Dan Leverage Terhadap Perataan Laba Pada Perusahaan Yang Terdaftar Di BEI . ( Studi Empiris Pada Perusahaan Perbankan Di BEI )

Butar, LKB., \& Sudarsi, S. (2012). Pengaruh Ukuran Perusahaan, Profitabilitas, Leverage, Dan Kepemilikan Institusional Terhadap Perataan Laba: Studi Empiris Pada Perusahaan Food And Beverages Yang Terdaftar Di BEI. Dinamika Akuntansi, Keuangan dan Perbankan, Nopember 2012, Hal: 143 - 158 Vol. 1, No. 2

DEWI, D.O. (2010). Pengaruh Jenis Usaha, Ukuran Perusahaan Dan Financial Leverage Terhadap Tindakan Perataan Laba Pada Perusahaan Yang Terdaftar Di Bursa Efek Indonesia

Hutamanjaya, H.P. (2019). Faktor-Faktor Yang Mempengaruhi Tindakan

Perataan Laba (Studi Empiris Pada Perusahaan Property Dan Real Estate Yang Terdaftar Di BEI Tahun 2015- 2017)

PRASETYA, H. (2013). Pengaruh Ukuran Perusahaan, Profitabilitas, Financial Leverage, Klasifikasi Kap Dan Likuiditas Terhadap Praktik Perataan Laba

Rahmawati, D. (2012). Analisis Faktor- Faktor Yang Berpengaruh Terhadap Praktik Perataan Laba 